\title{
U- Banking: The Next Generation E-Banking
}

\author{
Peter John
}

\begin{abstract}
The convergence of technology, business and communication brings several changes in the way of doing banking business. The development in the field of ubiquitous computing adds another dimension to traditional E-Banking in the form of $U$-Banking. It stands for a world in which customers can approach to any net work from any place and in any time by using various technology devices in order to get unique and personalized service. It includes banking transactions in all directions in a ubiquitous environment. The emergence of $U$-Banking could be viewed as an extension of E-Banking and M-Banking. This paper aims to clarify the concept of $U$-Banking as well as to identify its components and major challenges.
\end{abstract}

Key words: Ubiquitous, Ubiquitous computing, U-Banking, Unison

\section{Introduction}

The rate of Technological development is accelerating and products and processes are evolving at a more rapid pace and it re-defines the way of doing banking business. The convergence of business, technology and communication has plunged us into a dynamic economic environment. E-Banking and Mobile banking capabilities are bringing us closer together and empowering individuals as never before. The development in the field of Ubiquitous computing paves way to the emergence of ' $U$-Banking'-ubiquitous or universal banks, where traditional barriers of time, geography, currency and access have ceased to exist.

\section{Concept of U- Banking}

The concept of U-Banking has emerged as a logical extension e-banking and m-banking and the $U$ stands for Ubiquitous. It is the result of the drastic change raised in banking business model due to rapid development of ubiquitous computing. The intention of ubiquitous computing is to create a computing infrastructure that permeates our physical environment so much that we do not notice the computer any longer. It is the computing technology that permits human interaction away from a single work station. That means every device or products we uses will contain a processor. Alan Dix and Janet Finley' in their book 'Humancomputer interaction' give a good analogy for the vision of ubiquitous computing of electric motor. When electric motor was first introduced, it was large, loud and very noticeable. Today, the average household contains so many electric motors that we hardly ever notice them anymore. Their utility led to ubiquity and hence invisible.

\section{Characteristics of U-banking}

U-banking should be the ubiquitous, universal, unique and unison ${ }^{3}$. These are nowadays accepted as the major characteristics of U- banking and can be expressed as the $4 \mathrm{Us}$.
1. Ubiquitous
2. Universal
3. Unique
4. Unison

1. Ubiquitous- Ubiquity allows the users to access the networks or devices from anywhere, at any time. One day a micro chip will be in every manufactured product to make every object as the part of ubiquitous network. These offers reach ability, accessibility, and portability.

2. Universal - Universality will eliminate the problem of incompatibility caused by the lack of standardization, so the people have universal devices that stay connected regardless of their locations. So they can access any mobile networks from any mobile devices.

3. Unique- Uniqueness suggests that users can be uniquely identified not only by identity and preferences, but also in terms of geographical positions. Thus it incorporates the idea of identification, personalization and localization.

4. Unison-unison allows data to be integrated across different applications so that customers of the banks have a consistent view of information. If a customer have desk top computer, lap top computer, mobile phone and tablet computer, unison will enable any change in one of the device will be registered in all others. 


\section{Components of $\mathbf{U}$ - banking:}

a. Traditional e-banking- E-banking is the most established type of banking performed through digital means. Banks are using it as a part of their traditional business or as a pure online banking model. By the way, ebanking uses Internet for both communication and business transactions.

b. Ubiquitous banking or U-banking is the combination of traditional e-banking and wireless, television, voice and silent banking. This combination enables interaction and transaction anywhere and everywhere, even without online connection. Thus, U- banking integrating five types of business models

c. Traditional e-banking -E-banking is the type of banking performed through digital means. Banks are using it as a part of their traditional banking or as a pure online banking business model. By the way, e-banking uses Internet for both communication and banking transactions.

d. M-banking (Mobile banking) - Wireless banking is a key part of u-banking, because it creates the possibility for communications between people, businesses, banks and objects to happen anywhere and anytime. Mobile and wireless devices are enabling banks to conduct business in more efficient and effective ways. Wireless banking use mobile and wireless devices for both communication and banking transactions.

e. V- Banking (Voice banking) - V-banking is a banking based on listening and speaking. An increasing number of businesses and banks are using computerized voice technologies: speech recognition, voice identification, and text-to-speech. Voice banking enables businesses to reduce call-center operating costs and improve customer service.

f. T-Banking(Television banking)- Television banking is a banking business model, which provides a new audio visual away and the diversity of choice by broadcasting the banking products information in the 24hour nonstop television channels.

g. S-banking (Silent banking)- Silent banking uses advanced tagging and sensor technologies, as well as wireless mobile communications, to make everyday objects intelligent and interactive, creating new information and value streams. Here the objects can communicate and banking business takes place without human interaction. For example, radio frequency identification (RFID) chips allow the tagging, tracking, and monitoring of objects along a bank's product's supply chain.

\section{U- Banking-Challenges}

Junglas and Watson ${ }^{3}$ are arguing that u-banking is opening new era in e-banking, starting with ebanking and continuing with $\mathrm{m}$-banking. At the same time it faces several challenges;

1. Scalability- during the phase of further development $U$ banking will include more and more customers, devices, applications and interaction among them. With the increase in the number of users and devices further development in applications will be needed.

2. Heterogeneity- there are many types of devices whether they are mobile phones or tablets and many of them are based on different plat forms of banking. This heterogeneity becomes an issue in order to ensure a standard and compactable U- banking environment.

3. Integration- Successful functioning of U-banking requires the integration of communication devices. Integration of communication devices in unique platform will be very complex. When increasing numbers of devices are connected the Servers are challenged and it may affect the reliability and quality of service.

4. Personalization and privacy paradox ${ }^{7}$-Personalization process with in U-banking is collecting information on customers who are memorized in their devices. This will help the banks to serve the customer in unique way. However, this process increases the, customer's concern over privacy protection issue.

5. Changes in organizational structure- U-banking king have significant implications for the firm's structure. Managers will need to consider what the nature and requirements of u-commerce will mean to existing structures and question whether they are still appropriate or to make modifications.

\section{Conclusion}

Ubiquitous computing has opened new possibilities for the banking business. In the context of U banking, the players will be offering new services, new payment tools, and a host of new ways to access to goods and services anytime, anywhere, and anyway. U- Banking could sweep away all notions about brick- and -mortar trade. It can solve many inconvenience of e-banking and can add several new dimensions too. On the basis of the capabilities and potential one can conclude that U-banking will be the next generation E-banking, which is more flexible and resilient. 


\section{References:}

[1]. Alan Dix, Janet Finlay, Gregory D, Abowd and Russell Beale,. Human-Computer Interaction, Dorling Kinderley(india) pvt.Ltd.2012

[2]. R.T Watson, “U-Commerce; The Ulitimate”, ubiquity, Vol.33,PP.1-2,2000.

[3]. R. T. Watson,Leyland F Pitt, Pierre Berthon and George M. Zinkhan; "U-commerce; expanding the universe of marketing," Journal of the Academy of Marketing Science.Vol.30, no.4, pages 329-343.

[4]. Mathew ,J.Sarkar, varshney, “M-Commerce Services: Promises and Challenges” Communications of AIS, Vol.2004 Issue-14, PP 111

[5]. 5 George S. Oreku, "Mobile technology interaction to e-Commerce in promising of u-Commerce"

[6]. Atiya Parveen, Sobia Habib \& Saoud Sarwar "Mobile Commerce - New Way to Business" International Journal of Research and Development - A Management Review (IJRDMR ) 2012Volume-1, Issue - 1, PP 37-40

[7]. Galanxhi-Janaqy, H., Nah, F.F-H.: “Privacy issues in the era of ubiquitous commerce”, Electronic markets, Vol. 16, No. 3, 2006, pp.222-232. 